\title{
USE OF ELEMENTS OF ARTIFICIAL INTELLIGENCE IN THE ANALYSIS OF INFOCOMMUNICATION TRAFFIC
}

Shakhmaran Zh. Seilov,

L. N. Gumilyov ENU, Nur-Sultan, Kazakhstan, seilov_shzh@enu.kz

Vadim Yu. Goikhman,

LLC "NTC "SOTSBI", Saint-Petersburg, Russia, vadgogo@gmail.com

Yerden Zhursinbek,

L. N. Gumilyov ENU, Nur-Sultan, Kazakhstan, zhursinbek@gmail.com

Mereilim N. Kassenova,

L. N. Gumilyov ENU, Nur-Sultan, Kazakhstan, mikassen@gmail.com

Daniyar S. Shingissov,

L. N. Gumilyov ENU, Nur-Sultan, Kazakhstan, shingissov@gmail.com

Akhmet T. Kuzbayev,

L. N. Gumilyov ENU, Nur-Sultan, Kazakhstan, akuzbaev@mail.ru
DOI: |0.36724/2072-8735-2020-|4-|2-66-7|

This work was partially supported by the Ministry of education and science of the Republic of Kazakhstan under Grant AP05 I34349.

Manuscript received 12 October 2020;

Accepted 23 November 2020

Keywords: artificial intelligence, expert systems, artificial neural networks, infocommunication traffic, search strategy, knowledge base

\begin{abstract}
Modern communication networks are based on multi-service networks, which are a single telecommunications structure that can transmit large volumes of multi-format information (voice, video, data) and provide users with a variety of information and communication services. Traffic transmitted in multiservice networks differs significantly from traditional traffic of telephone or other homogeneous networks. Knowledge of the nature of modern traffic is necessary for the successful construction, operation and development of multi-service communication networks, providing users with high-quality services, and efficient use of funds allocated for network development. To learn the properties of infocommunication traffic, new methodological techniques are currently used, as well as promising information technologies such as Big Data and data mining. The article is devoted to the use of such elements of artificial intelligence as expert systems and neural network technologies in relation to the analysis of infocommunication traffic. The article examines the structure of expert systems, analyzes the applied search strategies and decision-making methods. The article also provides an overview of the architecture of neural networks in relation to traffic analysis tasks. The traffic analysis task is a classification task. The feasibility of using multi-layer neural networks with direct signal propagation for traffic analysis is shown. The following neural network architecture was chosen: the input layer, in accordance with the dimension of the input signal, contained $5 \mathrm{I}$ neurons, two hidden layers with 20 and 10 neurons, respectively, and the output layer with five neurons, according to the number of specified types of distributions. The results obtained showed a satisfactory quality of the neural network developed and trained in the framework of the research.
\end{abstract}

Information about authors:

Shakhmaran Zh. Seilov, candidate of technical Sciences, doctor of Economic Science, professor, Dean of the faculty of information technologies of the L. N. Gumilyov ENU, Nur-Sultan, Kazakhstan.

Vadim Yu. Goikhman, candidate of technical Sciences, associate Professor, General director of LLC "NTC "SOTSBI", Saint-Petersburg, Russia. Yerden Zhursinbek, Ist year master student of the Department "Information security", ENU named after L. N. Gumilev, G. Nur-Sultan, Kazakhstan. Mereilim N. Kassenova, master of technical sciences, lecturer of the department of radio engineering, electronics and telecommunications, Vice-dean of the faculty of information technologies of the L. N. Gumilyov ENU, Nur-Sultan, Kazakhstan.

Daniyar S. Shingissov, master of engineering and technology, 2nd year doctoral student of the Department of Information systems, ENU named After L. N. Gumilyov, Nur-Sultan, Kazakhstan.

Akhmet T. Kuzbayev, master of engineering and technology, 2nd year doctoral student of the Department of Information systems, ENU named after L. N. Gumilyov, Nur-Sultan, Kazakhstan.

Для цитирования:

Сеилов Ш.Ж., Гойхман В.Ю., Журсинбек Ерден, Касенова М.Н., Шингисов Д.С., Кузбаев А.Т. Использование элементов искусственного интеллекта при анализе инфокоммуникационного трафика // Т-Сomm: Телекоммуникации и транспорт. 2020. Том 14. № 12. С. 66-7I.

For citation:

Seilov Sh.Zh., Goikhman V.Yu., Zhursinbek Yerden, Kassenova M.N., Kuzbayev A.T. (2020) Use of elements of artificial intelligence in the analysis of infocommunication traffic. T-Comm, vol. 14, no.12, Pp. 66-7I. (in Russian) 


\section{Introduction}

Research in the field of artificial intelligence is one of the important areas of digitalization of the world community.

The telecom industry is projected to invest tens billion dollars in artificial intelligence technology in the coming years. These technologies will find their application in forecasting systems, analytics, network infrastructure management, intelligent traffic analysis [4].

Intelligent systems are being developed in the field of artificial intelligence. The purpose is to solve complex problems in which logical information processing prevails over computing.

Within the framework of infocommunication traffic analysis, at least two subsections of artificial intelligence can be used $[2,3]$. These are expert systems on the knowledge base about traffic and allowing to form decisions by methods of logical search and structured knowledge extraction and systems of quick decision making on neural network technologies [1].

\section{Expert systems}

With the development of computer technology, development of information structures for presentation of data took place. First, there were various ways of describing data, lists, hierarchical structures. The next step was the emergence of databases that could store large amounts of information. Database management systems DBMS, made it possible to efficiently retrieve or write them in the desired order, search for data, etc. Finally, the emergence of intelligent systems became the basis for concept of knowledge emergence.

Knowledge is associated with data, based on them, but is the result of intellectual activity, generalizes the existing experience - we can say that knowledge is the identified patterns of the subject area.

The knowledge base is a necessary component of artificial intelligence systems and expert systems. Any knowledge base contains a database as a component, but is not limited to it. The main difference between the knowledge base and the database is that from the database you can extract only the factual information that is included in it, and from the knowledge base you can derive new facts that were not included in it.

A typical expert system consists of the following elements:

- processing unit;

- database;

- knowledge base;

- block of knowledge acquisition.

The database is designed to store the source data about the subject area.

The knowledge base is the main, central part of the expert system. It contains long-term data describing relationships, rules and methods for the appropriate transformation of data, i.e. for solving problems from the field of application of the expert system.

The processing unit, using the initial data from the database and knowledge from the knowledge base, forms a sequence of rules that, when applied to the initial data, lead to the solution of the problem.

The knowledge acquisition unit provides an interface for implementing the process of filling the expert system with knowledge.

Expert systems differ in the field of application and in the type of tasks being solved. They can be used independently and as built-in mechanisms that interact with other subsystems. The operation of expert systems may be subject to restrictions on the acceptable response time.

The use of an expert system in traffic analysis systems makes it possible to provide, on the basis of the received (observed) information about the traffic, the rules laid down in the knowledge base and the adopted search strategies - the formation of effective decisions on the classification and traffic recognition.

Traffic analysis tasks mainly require finding the necessary solution among alternatives. By representing a similar problem in the form of a state graph, you can use graph theory to find a solution. The vertices of the graph represent the states of the process, the arcs describe the transitions between the states. These transitions correspond to logical conclusions. States describe knowledge about a task at a certain stage, and the application of rules is represented as a transition between states [5].

The state from which the solution of the problem begins is called the initial state. The set of states reachable from the initial one is the state space. A path is a sequence of vertices leading from the initial state to the target, the number of these vertices is the length of the path.

The process of finding the path along the graph from the initial state to the top, which is the required one, i.e. to the target state is called a search strategy. Search strategies can be different, therefore, the assessment, which will characterize the effectiveness of the selected search strategy, should take into account, and the possibility of achieving the goal in general and depends on the length of the path and the required time [14].

In general, search strategies are divided into two large groups: "blind" search and "directed" search.

The group of "blind" search strategies includes: the breadthfirst search strategy, the depth-first search strategy, and the counter-search strategy.

One of the most obvious search strategies is called Breadth First Search. The search starts from the root node, all the followers of the root node are determined, then all the followers of each of the followers of the root node, then all the followers of each of the followers found in the previous step, etc. until all the vertices corresponding to the target states are found. According to this strategy, vertices of depth $n$ are searched after all vertices of depth $n-1$ have been found. Due to the exponential nature of this strategy, it is inappropriate to use it for solving problems of large dimensions.

There is a modification of this strategy, in which the cost of the path to each of the available vertices is preliminarily estimated (using the evaluation function) and the search continues on the path with lowest cost. If the target vertex is reached, the search stops. This strategy reduces the overall time to find a solution.

The next known strategy is called the depth-first search strategy. When choosing this strategy, the search starts from the root vertex (level 1), then all vertices available to it are analyzed (level 2). If there is a target vertex among them, the search ends, if the target vertex is not found, and the final level of the graph has not yet been reached, then the leftmost vertex of level 2 is taken and all available vertices of level 3 are considered. If the target vertex is not found again, then the leftmost vertex of level 3 . Then, all incident vertices of level 4 are considered again.

This process continues until either all target vertices are found, or the maximum level of the graph is reached. In this case, an ascent up one level is carried out, the next top is selected 
at this level (from left to right) and further search is carried out using the same algorithm.

For problems with a small search tree, depth-first search may be useful, since there is a chance to find the target without looking at all the vertices of the graph. But for problems whose graph has a large number of levels, depth-first search may be ineffective, since it will strive all the time to the depth, while the goal may be close to the root of the tree, but on a path that has not yet been viewed.

There is a modification of this strategy called the limited depth-first search strategy. Its essence lies in the fact that the level number (radius) is set, upon reaching which there is a return to the previous level. A further modification of this strategy is to iteratively apply limited depth search, first the search radius is set to 1 , then 2,3 , etc. This search option is not always advisable, since some of the vertices are viewed many times, however, for tasks with a large search space and unknown depth, its use is justified.

The oncoming search strategy is based on the simultaneous search from the root to the target (forward search) and from the target to the root (reverse search). The process ends at the moment when both searches meet in the middle of the graph. This strategy can be effective if the degree of branching and the complexity estimate in both directions are comparable.

All blind search strategies have exponential estimates of complexity and are therefore suitable for relatively small problems. In directed search strategies, the next vertex is selected based on the selected criterion, the set of all vertices is ordered according to this criterion, and the one for which the criterion has best value is selected from the set of alternative vertices. Below are examples of targeted search strategies.

Search strategy based on the criterion of proximity to the target. The criterion for proximity to the target is usually a certain function calculated for the analyzed vertex and characterizing the proximity of this vertex to the target.

When using the criterion of proximity to the target, starting from the root vertex, all vertices available to it are scanned, and the one for which the criterion value is minimal is selected, and so on until the target vertex is reached, i.e. the top that is closest to the target is selected. Search based on the criterion of proximity to the target is a depth-first search, but with a choice at each step of a single vertex from which the next step begins. The disadvantages of this strategy are the same as for blind depth-first search, it can happen that the search goes on an endless path and never comes back.

The path cost search strategy is similar to the proximity search strategy, but it uses more complex criteria. This criterion includes the characteristic of vertex proximity to the goal and the characteristic of transition complexity.

The strategy of optimizing iterative search is to find such an order of traversing the vertices, which makes it possible to reach the target vertex. One example of such a strategy is gradient search. The idea of gradient search is to move "up", ie, towards the vertex, which is characterized by a higher quality criterion value than the previous one.

However, if there are several extrema (from the point of view of the quality criterion), then there is a danger of getting to a local extremum, where the search process will stop. Therefore, after stopping the gradient search process, the next iteration of the search is performed.
The previous found state is retained until a better one is found. The choice of the most effective search strategy depends on the specific problem being solved, the requirements of the available resources and capabilities. The search processes inherent in expert systems used in traffic analysis $[11,12,13]$, as a rule, have significant branching and a small depth of the state space, which makes it possible to effectively use the search strategy based on the path cost criterion.

A significant part of the algorithms used in training neural networks are based on the strategy of optimizing iterative search (gradient descent algorithms).

This circumstance allows us to highlight the specified strategy for the systems of analysis of infocommunication traffic $[6,7,8]$. Traffic analysis is reduced to a decision-making process based on the available and received information and the accepted rules for processing this information.

The solution might be:

- in choosing one of the alternative options;

- finding a fact;

- in evaluating the value;

- in recognition.

Since the available information does not fully describe the real conditions, i.e. we are talking about making decisions in conditions of uncertainty, the use of strictly logical reasoning cannot be the main method of making decisions. Uncertainty in complex systems is always present, it is due to the limited nature of our knowledge and the ability to obtain all the necessary information. In such conditions, we are talking about a probabilistic approach to the formation of decisions.

The consequences of the decision made are the criterion for its correctness. The correspondence of these consequences to the expected result can be expressed by some measure that estimates the losses from a given decision, which is a loss function. Minimizing this function determines the most appropriate solution.

In artificial intelligence systems, an approach to decision making is actively developing, based on fuzzy logic and fuzzy sets, using the concept of ignorance - ignorance about the degree of truth of some event. In fuzzy logic, instead of the values "true" and "false", the value "degree of truth" is used, which takes any values from an infinite set from 0 to 1 .

Using a probabilistic approach as a model for uncertainty is the dominant method and basis for statistical decisions. Since the uncertainty arising in the process of traffic analysis is not of the nature of ignorance, but is determined by the degree of probability, it is advisable to use probabilistic methods in these systems, within the framework of statistical information processing.

\section{Neural network technologies}

Another direction of artificial intelligence used in traffic analysis is based on a neural model of the brain based on the interpretation of the activity of the nervous system, in contrast to expert systems, which were based on modeling the human decision-making process, through the use of the laws of formal logic, set theory, graph theory, etc. Artificial neural networks demonstrate properties inherent in the brain: they learn from experience and generalize essential properties from incoming information.

Training. Artificial neural networks can change their behavior depending on the external environment. After the input signals are supplied (paired with the required outputs), they self- 
adjust to provide the required response. Many different training algorithms are known, each of which has its own advantages and disadvantages.

Generalization. Trained neural networks are resistant to small changes in input signals, i.e., they have the ability to recognize an image through noise and distortion. It is important that this is an intrinsic property of the neural network, implemented thanks to the structure, and not using additional software.

Applicability. Artificial neural networks are not a "panacea". They are of little use for performing tasks of a rigorous computational nature, however, they have proven themselves very well in complex algorithmic tasks, for example, in pattern recognition tasks that ordinary computers do poorly.

In recent years, there has been an explosive interest in neural networks, which are successfully used in various fields, in particular, in the field of telecommunications.

Neural networks have come into practice wherever it is necessary to solve problems of forecasting, classification or management, it should be noted that these aspects are inextricably linked with traffic analysis. Neural networks arose from research in the field of artificial intelligence, namely from attempts to reproduce the ability of biological nervous systems to learn and correct errors by simulating the low-level structure of the brain [6].

The human brain consists of a very large number (approximately $10,000,000,000)$ of neurons connected by numerous connections (on average, several thousand connections per neuron, but this value can vary greatly).

A neuron is a special cell capable of transmitting electrochemical signals. When activated, a neuron sends an electrochemical signal along its axon, and through synapses, this signal reaches other neurons, which can, in turn, be activated. A neuron is activated when the total level of signals arriving in its nucleus from dendrites exceeds a certain level (activation threshold).

Artificial neural networks are an ordered community of artificial neurons. Each artificial neuron is a simplified model of a biological neuron and consists of an input adder, a nonlinear transformer, and a branch point at the output. The orderliness is that neurons are combined into layers. The outputs of some neurons are connected to the inputs of others, and certain weights are assigned to the inputs of the neurons. Signals that determine the input data of the problem being solved are sent to the inputs of the neurons of the first layer. These signals are summed, taking into account the weights assigned to the inputs of the neuron, that is, taking into account the significance of each input and are transmitted to the inputs of the neurons of the next layer. The signals generated by the neurons of the output layer are interpreted as a solution to the problem.

By architecture, neural networks are divided into single-layer and multi-layer.

In single-layer neural networks, signals from the input layer are immediately fed to the output layer, where the necessary calculations are made, the results of which are immediately fed to the outputs. It should be noted that single-layer networks have limited functionality, in contrast to the widely used multilayer networks.

In multilayer networks, neurons are grouped into layers. In addition to the input and output layers, there are inner layers, which are called hidden. The number of hidden layers is unlimited, if there are more than 1 hidden layers, the neural network is considered deep.
Multilayer networks with direct signal propagation effectively solve problems in which the input vector completely determines the task at hand, and the current solution does not depend on the history in any way.

Although such networks are a universal tool, nevertheless, the main purpose of these networks is to solve classification problems. Feedback networks (recurrent networks) - allow you to process information in which not only the content is important, but also the order in which the information is received.

The main direction of using such networks is clustering tasks. Convolutional neural networks - got their name from the "convolution" operation they implement. The main purpose of convolutional neural networks is pattern recognition.

To obtain reliable results, before using the neural network, it is necessary to carry out its training procedure, during which the weights of the inputs of the neurons are adjusted so that the correct answer is formed on the incoming input data.Существуют два основных метода обучения нейронных сетей - «с учителем» и «без учителя».

Supervised learning assumes that during training there are many pairs of vectors $\{(\mathrm{X}, \mathrm{Y})\}$, where $\mathrm{xi}$ is one of the vectors that specify the problem condition, and yi is the solution for the vector xi. During training, the network changes its weights so as to form the required mapping $\mathrm{X} \rightarrow \mathrm{Y}$. It should be noted that the size of the set of training pairs must be large enough.

The unsupervised learning method is used when only the input vectors are known. When these vectors are presented, the network self-organizes, adjusting its weights in such a way as to form the same results for sufficiently close input influences. In fact, in this case, the neural network looks for patterns in the training data and performs grouping of similar input vectors by implicit criteria.

These methods are implemented in a very large number of different specific training algorithms, each of which uses its own search strategies. Based on the results of the analysis of neural network models [19], given that one of the essential tasks of traffic analysis is classification, it can be concluded that it is advisable to use multilayer neural networks with direct signal propagation in traffic analysis tasks.

Taking into account the above statement, a neural network was developed to determine the closest type of distribution of probabilistic characteristics of campus traffic $[9,10]$.

The following neural network architecture was chosen: the input layer, in accordance with the dimension of the input signal, contained 51 neurons, two hidden layers with 20 and 10 neurons, respectively, and the output layer with five neurons, according to the number of specified types of distributions were used [19].

The neurons in the layers were interconnected according to the principle "each with each". All connections of two neurons were assigned a certain weighting coefficient, which was then adjusted by the network during training. The hidden layers used the sigmoidal activation function, and the output used the softmax activation function. This function generates the values of the output vector in the range from 0 to 1 , which makes it possible to interpret the values of the output vector as the probability that the input signal belongs to one of the typical distributions. To train the neural network, pre-formed training and test samples containing 30 thousand input vectors of each of the given distributions were used. 
Traffic analysis [18], using a neural network, showed that the distribution of its parameters was closest to the Pareto distribution, which is consistent with the theoretical assumptions [16,17].

\section{Conclusion}

To verify the result of the neural network using the least squares method, an estimate was made of how closely the Pareto distribution approximates the investigated characteristic of the original traffic [15], in comparison with other investigated distributions. The results obtained showed a satisfactory quality of the work developed and trained in the framework of the research of the neural network. Thus, it can be concluded that it is advisable to use such artificial intelligence subsystems as expert systems and artificial neural networks in traffic analysis.

\section{References}

1. V.I. Komashinsky, D.A. Smirnov (2003). Neural networks and their application in control and communication systems. Moscow: Hotline-Telecom. 94 p.

2. Nick Bostrom (2016). Artificial intelligence. Stages. Menaces. Strategies; translated from English by S. Filin. Moscow: Mann, Ivanov and Ferber.

3. A.E. Kononyuk (2017). Fundamentals of the fundamental theory of artificial intelligence. Books 1,2,3. Kiev: Education of Ukraine. $730 \mathrm{p}$.

4. S.N. Stepanov (2010). Fundamentals of teletraffic of multiservice networks. Moscow: Eco-Trends. 392 p.

5. B.S. Goldshtein, N.A. Sokolov, G.G. Yanovsky (2010). Communication Networks. Saint Petersburg: BHV-Petersburg. 400 p.

6. V.Yu. Goikhman, A.I. Lapiy (2016). Building a neural network architecture to identify the type of distribution of random variables. Technologies and communication tools. No. 3. P. 36-40.

7. V.Yu. Goikhman, A.I. Lapiy (2018). Research of probabilistic characteristics of traffic using the neural network apparatus. Elektrosvyaz. No. 4. P. 64-67.

8. V.Yu. Goikhman, A.I. Lapiy (2016). Solution of the problem of traffic classification using a neural network. Proceedings of educational institutions of communications. Vol. 2. No. 1. P. 43-47.
9. V.Yu. Goikhman, T.Yu. Lushnikova (2017). Characteristic features of campus traffic. Moscow: Elektrosvyaz. No. 4. P. 40-44.

10. V.Yu. Goikhman, T.Yu. Lushnikova, Yu.A. Zinenko (2016). Traffic analysis of student dormitories. Bulletin of Cybernetics. No. 1 (21).

11. O.I. Shelukhin, A.V. Osin, S.M. Smolsky (2008). Selfsimilarity and fractals: telecommunication applications. Moscow: Fizmatlit. 368 p.

12. M.A. Schneps-Schnappe (1974). Numerical methods of the theory of teletraphy. Moscow: Svyaz. $232 \mathrm{p}$.

13. G.P. Basharin (2004). Lectures on the mathematical theory of teletraphy. Moscow: RUDN. 193 p.

14. M.N. Kassenova, L.N. Korganbayeva (2018). Research issues reliable and current characteristics of information and communication traffic. XIII International Scientific Conference of students and oung Scientists «Science and education - 2018», L. N. Gumilyov Eurasian National University, Astana. P. 219-222.

15. Sh.Zh. Seilov, L.N. Korganbayeva, M.N. Kassenova, V.Yu. Goikhman, M.M. Marshak (2018). Systematization of parameters characterizing information and communication traffic. Astana. Professional journal on telecommunications: Information and telecommunications networks. No.5 (141-142). P. 43-48.

16. V. Goikhman, Sh. Seilov, N. Sokolov, L. Korganbayeva (2019). Evaluating the packet traffic parameter measurements. Telecommunications and Radio Engineering. No.78 (6). P. 489-499.

17. V. Goykhman, L. Korganbaeva, A. Ermakov, M. Nikolaeva (2019). Research of Typical Information Objects Traffic. Advances in Science and Technology Research Journal. Vol. 13, Issue 2, June 2019. P. 51-55.

18. Sh.Zh. Seilov, S.N. Boranbayev, M.N. Kassenova, A.A. Seilov, D.S. Shingisov (2019). Intellectual analysis of information and communication traffic. Bulletin of the L. N. Gumilyov Eurasian National University. Series Technical Sciences and technologies. No. 3 (128). P. 76-86.

19. Sh. Seilov, V. Goykhman, M. Kassenova, A. Seilov, D. Shingissov (2019). Development of neural network models for the analysis of infocommunication traffic. Bulletin of the Karaganda University. Mathematics series. №2019-96-4. P.118-126.

\title{
ИСПОЛЬЗОВАНИЕ ЭЛЕМЕНТОВ ИСКУССТВЕННОГО ИНТЕЛЛЕКТА ПРИ АНАЛИЗЕ ИНФОКОММУНИКАЦИОННОГО ТРАФИКА
}

\begin{abstract}
Сеилов Шахмаран Журсинбекович, ЕНУ имени Л.Н.Гумилева, г. Нур-Султан, Казахстан, seilov_shzh@enu.kz Гойхман Вадим Юрьевич, ООО "НТЦ "СОТСБИ", г. Санкт-Петербург, Россия, vadgogo@gmail.com Журсинбек Ерден, ЕНУ имени Л.Н.Гумилева, г. Нур-Султан, Казахстан, zhursinbek@gmail.com Касенова Мерейлим Нурлановна, ЕНУ имени Л.Н.Гумилева, г. Нур-Султан, Казахстан, mikassen@gmail.com Шингисов Данияр Серикович, ЕНУ имени Л.Н.Гумилева, г. Нур-Султан, Казахстан, shingissov@gmail.com Кузбаев Ахмет Талгатбекович, ЕНУ имени Л.Н.Гумилева, г. Нур-Султан, Казахстан, akuzbaev@mail.ru
\end{abstract}

Данная работа выполнена в рамках проекта АР05 34349 "Интеллектуальная система анализа инфокоммуникационного трафика" грантового финансирования Комитета Науки Министерства науки и образования Республики Казахстан на 2018-2020 годы.

\section{Аннотация}

Основу современных сетей связи составляют мультисервисные сети, представляющие собой единую телекоммуникационную структуру, способную передавать большие объемы мультиформатной информации (голос, видео, данные) и предоставлять пользователям разнообразные инфокоммуникационные сервисы. Трафик, передаваемый в мультисервисных сетях, значительно отличается от традиционного трафика телефонных или иных однородных сетей. Знание природы современного трафика необходимо для успешного построения, эксплуатации и развития мультисервисных сетей связи, предоставления пользователям качественных услуг, эффективного использования средств, выделяемых на развитие сетей. Для изучения свойств инфокоммуникационного трафика в настоящее время используют новые методологические приемы, а также перспективные информационные технологии как Big Data и интеллек- 
туальный анализ данных - Data Mining. Статья посвящена вопросам использования таких элементов искусственного интеллекта, как экспертные системы и нейросетевые технологии, применительно к анализу инфокоммуникационного трафика. Рассматриваются структура экспертных систем, анализируются применяемые стратегии поиска и методы принятия решений. Задача анализа трафика относится к классу задач классификации. В статье приводится обзор архитектуры нейронных сетей. Для анализа трафика использована многослойная нейронная сеть с прямым распространением сигналов. Была выбрана следующая архитектура нейронной сети: входной слой, в соответствие с размерностью входного сигнала, содержал 51 нейрон, использовались два скрытых слоя с 20 и 10 нейронами соответственно и выходной слой с пятью нейронами, по числу заданных видов распределений. Полученные результаты показали удовлетворительное качество работы разработанной и обученной в рамках проведенных исследований нейронной сети.

Ключевые слова: искусственный интеллект, экспертные системы, искусственные нейронные сети, инфокоммуникационный трафик, стратегия поиска, база знаний

\section{Литература}

І. Комашинский В.И., Смирнов Д.А. Нейронные сети и их применение в системах управления и связи. М.: Горячая линия-Телеком, 2003.94 с.

2. Бостром Н. Искусственный интеллект. Этапы. Угрозы. Стратегии; пер. с англ. С. Филина. М.: Манн, Иванов и Фербер, 2016.

3. Кононюк А.Е. Основы фундаментальной теории искусственного интеллекта. Кн. І,2,3. Киев: "Освіта України", 2017.730 с.

4. Степанов С.Н. Основы телетрафика мультисервисных сетей. М.: Эко-Трендз, 20І0. 392 с.

5. Гольдштейн Б.С., Соколов Н.А., Яновский Г.Г. Сети связи. СПб: БХВ - Петербург, 20І0. 400 с.

6. Гойхман В.Ю., Лапий А.И. Построение архитектуры нейронной сети для выявления вида распределения случайных величин // Технологии и средства связи. 2016. № 3. С. 36-40.

7. Гойхман В.Ю., Лапий А.И. Исследование вероятностных характеристик трафика при помощи аппарата нейронных сетей // Электросвязь. 2018. № 4. С. 64-67.

8. Гойхман В.Ю., Лапий А.И. Решение задачи классификации трафика с использованием нейронной сети // Труды учебных заведений связи. 2016.

T. 2, № I. C. 43-47.

9. Гойхман В.Ю., Лушникова Т.Ю. Характерные черты кампусного трафика // Электросвязь. 2017. № 4. С. 40-44.

ІО. Гойхманн В.Ю., Лушникова Т.Ю., Зиненко Ю.А. Анализ трафика студенческого общежития // Вестник кибернетики. 20І6. № I(2I).

II. Шелухин О.И., Осин А.В., Смольский С.М. Самоподобие и фракталы: телекоммуникационные приложения. М.: Физматлит, 2008.368 с.

12. Шнепс-Шнепnе М.А. Численные методы теории телетрафика. М.: Связь, 1974. 232 с.

13. Башарин Г.П. Лекции по математической теории телетрафика. М.: РУДН, 2004. 193 с.

14. Касенова М.Н., Корганбаева Л.Н. Проблемы исследования вероятностно-временных характеристик информационно-коммуникационного трафика // XIII Международная научная конференция студентов и молодых ученых "Наука и образование - 20I8", Евразийский национальный университет имени Л.Н.Гумилева, Астана. 2018. С. 219-222.

15. Сеилов Ш.Ж., Корганбаева Л.Н., Касенова М.Н., Гойхман В.Ю., Маршак М.М. Систематизация параметров, характеризующих информационнокоммуникационный трафик. Астана // профессиональный журнал о телекоммуникациях:Информационные телекоммуникационные сети, 2018. №5 (I4I-I42). C. 43-48.

16. Goikhman V., Seilov Sh., Sokolov N., Korganbayeva L. Evaluating the packet traffic parameter measurements // Telecommunications and Radio Engineering, №78 (6), 2019. P. 489-499.

17. Goykhman V., Korganbaeva L., Ermakov A., Nikolaeva M. Research of Typical Information Objects Traffic // Advances in Science and Technology Research Journal, Vol. I3, Issue 2, June 2019. P. 5I-55.

18. Сеилов Ш.Ж., Боранбаев С.Н., Касенова М.Н., Сейлов А.А., Шингисов Д.С. Интеллектуальный анализ информационно-коммуникационного трафика // Вестник Евразийского национального университета имени Л.Н. Гумилева. Серия Технические науки и технологии. №3(I28), 2019.

C. 76-86.

19. Seilov Sh., Goykhman V., Kassenova M., Seilov A., Shingissov D. Development of neural network models for the analysis of infocommunication traffic // Bulletin of the Karaganda University. Mathematics series. №2019-96-4. P. II8-126.

\section{Информация об авторах:}

Сеилов Шахмаран Журсинбекович, к.т.н., д.э.н., профессор, декан Факультета информационных технологий ЕНУ имени Л.Н.Гумилева, 2. Нур-Султан, Республика Казахстан

Гойхман Вадим Юрьевич, к.т.н., доцент, генеральный директор ООО "НТЦ "СОТСБИ", г. Санкт-Петербург, Россия

Журсинбек Ерден, магистрант I курса кафедры "Информационная безопасность", ЕНУ имени Л.Н.Гумилева, г. Нур-Султан, Республика Казахстан Касенова Мерейлим Нурлановна, магистр технических наук, преподаватель кафедры "Радиотехника, электроника и телекоммуникации", зам. декана Факультета информационных технологий ЕНУ имени Л.Н.Гумилева, г. Нур-Султан, Республика Казахстан

Шингисов Данияр Серикович, магистр техники и технологий, докторант 2 курса кафедры "Информационные системы", ЕНУ имени Л.Н.Гумилева, г. Нур-Султан, Республика Казахстан

Кузбаев Ахмет Талгатбекович, магистр техники и технологий, докторант 2 курса кафедры "Информационные системы", ЕНУ имени Л.Н.Гумилева, г. Нур-Султан, Республика Казахстан 